\title{
The prevention of 2,4-
}

\section{dinitrochlorobenzene-induced} \section{inflammation in atopic dermatitis-like skin lesions in BALB/c mice by Jawoongo}

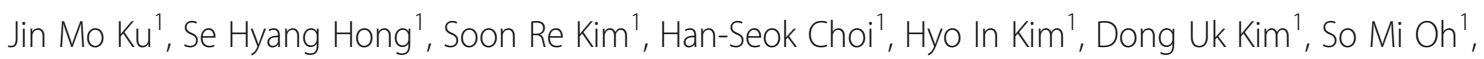
Hye Sook Seo ${ }^{2}$, Tai Young Kim ${ }^{2}$, Yong Cheol Shin ${ }^{2}$, Chunhoo Cheon ${ }^{2^{*}}$ and Seong-Gyu Ko ${ }^{2^{*}}$ (D)

\begin{abstract}
Background: Jawoongo is an herbal mixture used in traditional medicine to treat skin diseases. This study aimed to investigate whether Jawoongo ameliorates Atopic dermatitis (AD)-like pathology in mice and to understand its underlying cellular mechanisms.

Methods: AD was induced by 2, 4-Dinitrocholrlbenzene (DNCB) in BALB/c mice. Treatment with Jawoongo was assessed to study the effect of Jawoongo on AD in mice. Histological Analysis, blood analysis, RT-PCR, western blot analysis, ELISA assay and cell viability assay were performed to verify the inhibitory effect of Jawoongo on $A D$ in mice.

Results: We found that application of Jawoongo in an ointment form on AD-like skin lesions on DNCB-exposed $\mathrm{BALB} / \mathrm{c}$ mice reduced skin thickness and ameliorated skin infiltration with inflammatory cells, mast cells and CD4+ cells. The ointment also reduced the mRNA levels of IL-2, IL-4, IL-13 and TNF-a in the sensitized skin. Leukocyte counts and the levels of IgE, IL-6, IL-10 and IL-12 were decreased in the blood of the DNCB-treated mice. Furthermore, studies on cultured cells demonstrated that Jawoongo exhibits anti-inflammatory activities, including the suppression of proinflammatory cytokine expression, nitric oxide (NO) production, and inflammation-associated molecule levels in numerous types of agonist-stimulated innate immune cell, including human mast cells (HMC-1), murine macrophage RAW264.7 cells, and splenocytes isolated from mice.
\end{abstract}

Conclusion: These findings indicate that Jawoongo alleviates DNCB-induced AD-like symptoms via the modulation of several inflammatory responses, indicating that Jawoongo might be a useful drug for the treatment of AD.

Keywords: Atopic dermatitis, Jawoongo, 2,4-dinitrochlorobenzene, Cytokine, Inflammation

\section{Background}

Atopic dermatitis $(\mathrm{AD})$ is the most common chronic inflammatory and chronically relapsing skin disease. The prevalence of $\mathrm{AD}$ has increased continuously, and approximately 10 million people worldwide are currently affected. The disease leads to a significantly reduced quality of life $[1,2]$. The pathogenesis of $\mathrm{AD}$ is not well

\footnotetext{
* Correspondence: pm.thehoo@gmail.com; epiko@khu.ac.kr

${ }^{2}$ Department of Preventive Medicine, College of Korean Medicine, Kyung Hee University, Kyungheedae-ro 26, Dongdaemun-gu, Seoul 02447, South Korea

Full list of author information is available at the end of the article
}

understood but appears to be associated with the activation of innate immune responses, including inflammation.

Common features of AD include excessive infiltration of inflammatory cells and granulated mast cells into AD skin lesions and high immunoglobulin E (IgE) levels and leukocyte counts in blood [3]. Notably, CD4+ T cells are critical for the development of allergic inflammatory diseases. CD4+ T cell activation induces the secretion of cytokines and chemokines and drives inflammation and allergic sensitization [4]. Furthermore, the development of $\mathrm{AD}$ has been attributed to the activation of mast cells $[5,6]$ and T-helper 2 (Th2)-dependent cells [7, 8]. Mast

(c) The Author(s). 2018 Open Access This article is distributed under the terms of the Creative Commons Attribution 4.0 International License (http://creativecommons.org/licenses/by/4.0/), which permits unrestricted use, distribution, and reproduction in any medium, provided you give appropriate credit to the original author(s) and the source, provide a link to the Creative Commons license, and indicate if changes were made. The Creative Commons Public Domain Dedication waiver (http://creativecommons.org/publicdomain/zero/1.0/) applies to the data made available in this article, unless otherwise stated. 
cells are activated by IgE through the high-affinity IgE receptor ( $\left.F_{c} R\right)[9,10]$. These cells are then recruited into AD skin lesions, where they promote skin hypersensitivity reactions by releasing histamine; prostaglandin D2 (PGD2); AD-related Th2 cytokines, including IL-4, IL-5, and IL-13; and proinflammatory cytokines, including IL-4 and IL-6.

Tacrolimus is an effective immunosuppressant that inhibits the production of various cytokines, such as IL-2, IL-4 and IL-5. Many studies have demonstrated that tacrolimus suppresses allergic cytokine production by $T$ cells $[11,12]$ and is effective against $A D$ in animal models [13-15]. Tacrolimus ointment is used for the treatment of AD in adults and children [16-18]. However, previous studies have shown that treatment with tacrolimus elevated total and specific IgE levels and caused transient burning and erythema in $\sim 60 \%$ of patients $[19,20]$. Consequently, the development of alternative remedies is necessary to reduce these side effects.

Jawoongo is a traditional herbal medicine composed of Lithospermum root and Angelica gigas Nakai (AGN). AGN contains numerous active ingredients, including decursin. In previous studies, decursin exhibited anti-allergic effects in an asthma model and anti-metastatic effects in colon cancer [21-23]. Decursin has also been used for the treatment of various dermatitis-associated skin diseases, including eczema and chilblain. Recent studies have indicated that decursin is effective in driving artificial wound healing and ameliorating skin inflammation [24-26]. As known as, DNCB allergens elicited a systemic immune response, because increased cytokine levels in the serum of mice [27].

We investigated effect of jawoongo in DNCB induced $\mathrm{AD}$ model in Balb/c mice. The goal of this study was to explore the effects of Jawoongo on 2,4-dinitrochlorobenzene (DNCB)-induced AD-like symptoms in BALB/C mice and several types of immune cell.

\section{Methods}

Preparation of Jawoongo ointment and tacrolimus ointment

Jawoongo ointment was supplied by Han-poong Pharm Co., Ltd. (Jeonjoo, Republic of Korea). Jawoongo is made from Lithospermum root and Angelica gigas Nakai (AGN). The main compound in Lithospermum root is shikonin. Shikonin inhibits inflammation and imflammasomes $[28,29]$. The main compounds in AGN are decursin and Nodakenin. Decursin and Nodakenin are known to inhibit inflammation. Additionally, decursin is known to inhibit the proliferation of ovarian cancer cells [30-32]. A $0.1 \%$ protopic tacrolimus ointment was also utilized (Astellas Pharma Tech, Japan). Tacrolimus is made from FK506, which has been used to treat dermatitis, as it suppresses the development of Th2 cells $[33,34]$.

\section{Animals}

Six-week-old male BALB/c mice were obtained from Orient Bio, Inc. (Seoul, Korea). The mice were maintained for 1 week under a controlled temperature $(23$ $\left.\pm 3{ }^{\circ} \mathrm{C}\right)$ and humidity $(55 \pm 15 \%)$ with a $12 \mathrm{~h}$ light $/ 12 \mathrm{~h}$ dark cycle before initiating the experiment. The body weights and food intake of the animals were measured once every 2 days. All procedures performed on the mice were approved by the animal care center of Kyung-Hee University (Kyung Hee University Study Proposal (SEOUL) - 12-014; Approval No. KHUASP(SE)-12-014). Upon completion of the experiment, the mice were anesthetized with a $1.2 \%$ avertin solution ( $0.5 \mathrm{~g}$ 2,2,2-tribromoethanol powder dissolved into $1 \mathrm{ml}$ 2-methyl-2-butanol and $39 \mathrm{ml}$ phosphate-buffered saline (PBS) at $55{ }^{\circ} \mathrm{C}$ ) that was filtered through a Nalgene $0.22-\mu \mathrm{m}$ filter (Thermo Fisher Scientific, Inc., Waltham, MA, USA) and sacrificed via exsanguination $[35,36]$.

\section{Induction of AD-like lesions and drug treatment}

The procedures used for the induction of AD-like lesions and the drug treatment are shown in Fig. 1. The mice were divided into four groups, with eight mice in each group: group 1, normal; group 2, DNCB; group 3, $\mathrm{DNCB}+$ tacrolimus; group 4, DNCB + Jawoongo. After shaving, the back skin of the mice was painted with 200 $\mu \mathrm{L}$ of a $2 \%$ DNCB solution over $1 \times 1 \mathrm{~cm}$ patches for one week and challenged again with $200 \mu \mathrm{L}$ of a $0.2 \%$ DNCB solution twice a week. Tacrolimus or Jawoongo was then applied to the sensitized skin for two weeks.

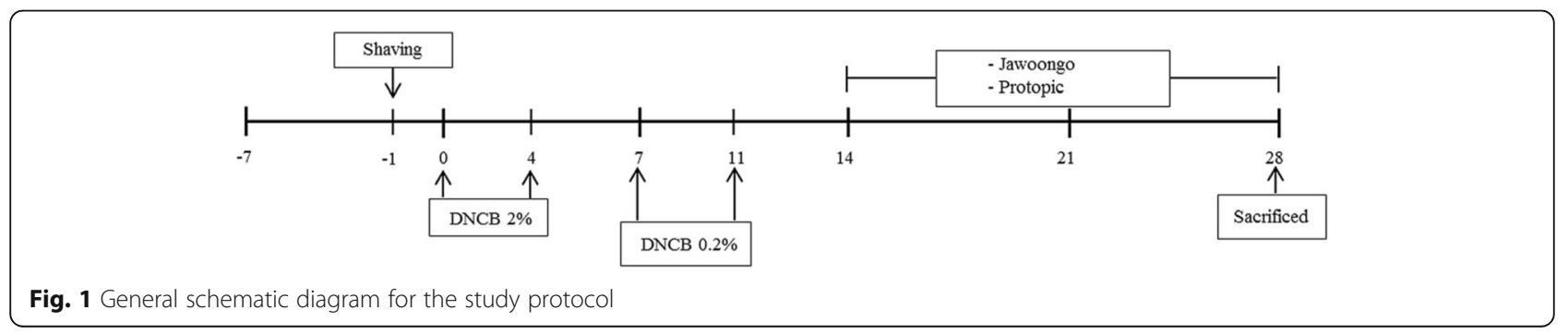


Following the last application of Tacrolimus or Jawoongo, the mice were sacrificed to perform immunological and histological assessments. The method was performed as described previously [37].

\section{Histological analysis}

Skin samples (20 $\mu \mathrm{m}$ thick) were embedded in Tissue-Tek optical cutting temperature (OCT) compound (Leica, CA, Richmond, USA). The skin samples were stained with hematoxylin and eosin (H\&E) to visualize inflammatory cells and with toluidine blue (TB) to visualize mast cells and then examined under a light microscope (Olympus). The mast cells and inflammatory cells were counted in 10 sections of high-power fields (HPFs) at 40x, 400x and $1000 \times$ magnification.

\section{Immunohistochemistry [38]}

CD4+ lymphocytes were detected by immunohistochemical analysis using anti-CD4+ antibodies (Santa cruz biotechnology, Dallas, Texas, USA). After deparaffinization, the slides were rehydrated and antigen retrieval done by microwave treatment, they were treated with 3\% hydrogen peroxide in PBS for 15 min to inhibit the endogenous peroxidase activity of blood cells. Following the hydrogen peroxide treatment, the sections were incubated with $5 \%$ bovine serum albumin (BSA) in PBS as a blocking reagent for $1 \mathrm{~h}$ at room temperature. The sections were then incubated with mouse monoclonal CD4+ antibodies (1:100 dilution) overnight at $4{ }^{\circ} \mathrm{C}$. After washing with PBS, subsequently incubated with secondary biotinylated anti-rabbit IgG for $1 \mathrm{~h}$ at room temperature. The sections were treated with an avidin-biotin HRP complex (Vectastain ABC kit, Vector Labs, CA, USA) for $30 \mathrm{~min}$ at $4{ }^{\circ} \mathrm{C}$ and stained with diaminobenzidine (DAB) tetrachloride as a substrate. The slides were mounted in an aqueous mounting solution (DAKO, Glostrup, Denmark) and cover-slipped. All of the sections were analyzed using an Olympus microscope, and images were captured using a digital video camera.

\section{Analysis of mouse blood}

Whole blood samples were collected by cardiac puncture and placed in Vacutainer TM tubes containing EDTA (BD Biosciences, USA) to prevent clotting. Anti-coagulated blood was processed to determine leukocyte counts, including lymphocytes, monocytes, eosinophils, basophils and neutrophils, using a HEMAVET 950 hematological analyzer (Drew Scientific, Inc., Oxford, USA).

\section{RT-PCR}

RNA was isolated using an Easy-blue RNA Extraction Kit (iNtRON biotech, Republic of Korea). In brief, we harvested cells (HMC-1, RAW264.7 and Splenocyte cells) and mouse tissue and $1 \mathrm{ml}$ of R\&A-BLUE solution was added to each. Following this, $200 \mu \mathrm{l}$ of chloroform was added to the lysate and then vigorously vortexed for $15 \mathrm{~s}$. Then, the lysate was centrifuged at $13,000 \mathrm{rpm}$ for $10 \mathrm{~min}$ at $4{ }^{\circ} \mathrm{C}$. We then transferred the appropriate volume of the aqueous phase into a clean tube, added $400 \mu \mathrm{l}$ of isopropanol and mixed the solution thoroughly by inverting the tube 6-7 times. After centrifuging the tube at $13,000 \mathrm{rpm}$ for $10 \mathrm{~min}$, the supernatant was carefully removed without disturbing the pellet. Then, $1 \mathrm{ml}$ of $75 \%$ ethanol was added, and the solution was thoroughly mixed by inverting the tube 4-5 times. The mixture was then centrifuged for $1 \mathrm{~min}$ at room temperature, and the supernatant was carefully discarded without disturbing the pellet. Finally, the remaining RNA pellet was dried and then dissolved in 20-50 $\mu$ l of RNase-free water. The concentration of the isolated RNA was determined using a NanoDrop ND-1000 spectrophotometer (NanoDrop Technologies Inc., Wilmington, USA). We treated DNase to each sample. Two micrograms of total cellular RNA from each sample was reverse-transcribed using a cDNA synthesis kit (TaKaRa, Otsu, Shinga, Japan). PCR was conducted in a $20 \mu \mathrm{L}$ reaction mixture consisting of a DNA template, $10 \mathrm{pM}$ of each gene-specific primer, 10× Taq buffer, $2.5 \mathrm{mM}$ dNTP mixture, and 1 unit of Taq DNA polymerase (Takara, Otsu, Shinga, Japan). PCR was performed using the specific primers listed in Table 1.

\section{Enzyme-linked immunosorbent assay}

Levels of IgE, IL-4, IL-6, IL-10, IL-12 and IL-13 were assessed using a Duoset enzyme-linked immunosorbent assay (ELISA) system (BD Biosciences, USA) according to the manufacturer's instructions. In brief, to assess the level of IgE, IL-4, IL-6, IL-10, IL-12 and IL-13 in the mice serum treated with Tacrolimus and Jawoongo, 96-well plates were coated with capture antibody in ELISA coating buffer and incubated overnight at $4{ }^{\circ} \mathrm{C}$. The plates were then washed with PBS with $0.05 \%$ Tween 20 (PBS-T) and subsequently blocked with $10 \%$ FBS in PBS for $1 \mathrm{~h}$ at $20{ }^{\circ} \mathrm{C}$. Serial dilutions of standard antigen or sample in dilution buffer (10\% FBS in PBS) were added to the plates, and the plates were incubated for $2 \mathrm{~h}$ at $20{ }^{\circ} \mathrm{C}$. After the plates were washed, biotin-conjugated anti-mouse IgE and streptavidin-conjugated horseradish peroxidase (SAv-HRP) were added to the plates, and the plates were incubated for $1 \mathrm{~h}$ at $20{ }^{\circ} \mathrm{C}$. Finally, the tetramethylbenzidine (TMB) substrate was added to the plates, and after $15 \mathrm{~min}$ of incubation in the dark, $2 \mathrm{~N}$ $\mathrm{H}_{2} \mathrm{SO}_{4}$ was added to stop the reaction. The optical 
Table 1 PCR primer sequences

\begin{tabular}{|c|c|c|}
\hline $\begin{array}{l}\text { Primer } \\
\text { Type } \\
\end{array}$ & $\begin{array}{l}\text { Primer } \\
\text { name }\end{array}$ & Primer Sequence \\
\hline \multirow[t]{12}{*}{ Mouse } & IL-2 & F: 5'-GCA GCT GTT GAT GGA CCT AC-3' \\
\hline & & R: 5'-TCC ACC ACA GTT GCT GAC TC-3' \\
\hline & $\| \mathrm{L}-4$ & F: 5'-TCG GCA TाT TGA ACG AGG TC-3' \\
\hline & & R: 5'-GAA AAG CCC GAA AGA GTC TC-3' \\
\hline & IL-13 & F: 5'-CGG CAG CAT GGT ATG GAG TG-3' \\
\hline & & R: 5'-ATT GCA ATT GGA GAT GTT GGT CAG-3' \\
\hline & iNOS & F: 5'-AAT GGC AAC ATC AGG TCG GCC ATC ACT-3' \\
\hline & & R: 5'-GCT GTG TGT CAC AGA AGT CTC GAA CTC-3' \\
\hline & TNF-a & F: 5'-ATG AGC ACA GAA AGC ATG ATC-3' \\
\hline & & R: 5'-TAC AGG CTT GTC ACT GGA ATT-3' \\
\hline & GAPDH & F: 5'-GAG GGG CCA TCC ACA GTC TTC-3' \\
\hline & & R: 5'-CAT CAC CAT CTT CCA GGA GCG-3' \\
\hline \multirow[t]{10}{*}{ Human } & $\mid \mathrm{L}-4$ & F: 5'-TGC CTC CAA GAA CAC AAC TG-3' \\
\hline & & R: 5'-CTC TGG TTG GCT TCC TTC AC-3' \\
\hline & IL-6 & F: 5'-AAC CTT CCA AAG ATG GCT GAA-3' \\
\hline & & R: 5'-CAG GAA CTG GAT CAG GAC TाT-3' \\
\hline & IL-13 & F: 5'-GGT CAA CAT CAC CCA GAA CC-3' \\
\hline & & R: 5'-TाT ACA AAC TGG GCC ACC TC-3' \\
\hline & TSLP & F: 5'-TAT GAG TGG GAC CAA AAG TAC CG-3' \\
\hline & & R: 5'-GGG ATT GAA GGT TAG GCT CTG G-3' \\
\hline & GAPDH & F: 5'-CGT CTT CAC CAC CAT GGA GA-3' \\
\hline & & R: 5'-CGG CCA TCA CGC CAC AGT TT-3' \\
\hline
\end{tabular}

density was measured at $450 \mathrm{~nm}$ on an automated ELISA reader. (Versa Max, Molecular Devices, CA, USA).

\section{Detection of nitric oxide}

Nitric oxide (NO) production from RAW264.7 cells in culture was measured using Griess reagent (Welgene, Korea). Briefly, $150 \mu \mathrm{L}$ of cell culture supernatant was mixed with $150 \mu \mathrm{L}$ of Griess solution and incubated for $30 \mathrm{~min}$ at room temperature. The optical density was determined at $570 \mathrm{~nm}$ using a microplate reader.

\section{Cell viability assay}

An MTS assay was performed to determine cell viability. To accomplish this, cells (HMC-1, RAW264.7 and Splenocyte cells) were seeded into a 96-well plate at a density of $3 \times 10^{3}$ cells per well and treated $24 \mathrm{~h}$ later with varying concentrations of Jawoongo $(5-500 \mu \mathrm{g} / \mathrm{mL})$ for an additional $24 \mathrm{~h}$. Ten microliters of WST solution was added to each well of the plate, which was incubated in the dark at $37{ }^{\circ} \mathrm{C}$ for another $2 \mathrm{~h}$. Optical density was measured at $450 \mathrm{~nm}$ using an ELISA plate reader.

\section{Western blot analysis}

Cells (HMC-1, RAW264.7 and Splenocyte cells) were lysed with cell lysis buffer (50 mM Tris-Cl pH 7.4, 1\% NP-40, 0.25\% sodium deoxycholate, 0.1\% SDS, $150 \mathrm{mM}$ $\mathrm{NaCl}, 1 \mathrm{mM}$ EDTA, and protease inhibitor). Twenty micrograms of protein was separated by SDS-polyacrylamide gel electrophoresis and transferred to a nitrocellulose membrane (Protran nitrocellulose membrane, Whatman, UK). The membrane was blocked with 5\% nonfat milk, probed with specific primary antibodies, incubated with HRP-conjugated secondary IgG antibodies (Calbiochem, San Diego, CA, USA), and visualized using an enhanced chemiluminescence detection system (Amersham ECL kit, Amersham Pharmacia Biotech Inc., Piscataway, NJ, USA). The antibodies against COX-2, p-JNK, total JNK and iNos were obtained from Cell Signaling (Danvers, MA, USA). The antibodies against p-Erk, total Erk, phospho-NF- $\mathrm{B}$ p65 (Ser536), total NF-kB and Actin were obtained from Santa Cruz Biotechnology (Dallas, Texas, USA). Tubulin antibody was obtained from Sigma-Aldrich (St. Louis, MO, USA).

\section{Isolation of Splenocytes}

Spleen suspensions from normal mice were prepared under aseptic conditions by homogenization in RPMI-1640 medium (containing 10\% FBS, 1\% antibiotics, and $0.05 \mathrm{mM} \beta$-mercaptoethanol). Red blood cell (RBC) lysis buffer (Sigma, St. Louis, MO, USA) was added to the cell suspension to remove RBCs. The spleen cells were centrifuged, suspended in complete RPMI-1640, and maintained at $37{ }^{\circ} \mathrm{C}$ in a humidified incubator with $5 \% \mathrm{CO}_{2}$.

\section{Liquid chromatography-mass spectrometry analysis.}

An Agilent 1100 series liquid chromatography-mass spectroscopy (LC-MS) with an atmospheric pressure chemical ionization interface was used in negative and positive ionization modes. Data were collected using Chemstation software version A.09.03. A Shiseido capcell-pak C18 column $(4.6 \mathrm{~mm} \times 150 \mathrm{~mm}, 5 \mu \mathrm{m})$ was used with an injection volume of $10 \mu \mathrm{L}$ for the HPLC separation. The mobile phases consisted of (A) Acetonitrile, (B) $0.1 \%$ Acetic acid and (C) Methanol at a flow rate of $1.0 \mathrm{~mL} / \mathrm{min}$. The gradient of the mobile phases (A: B: C) for separation was 0-90 $\min (35: 65: 0$ to 0: 0: 100). Decursin was used as standard. Mass spectrometry was operated with an electrospray ionization source and positive mode.

\section{Statistical analysis}

All experiment results were expressed as the means \pm SEM of at least three separate tests. Statistical significance at $P<0.05<0.01$ and $<0.001$ has been given respective symbols in the figures. Statistical analyses (ANOVA) were 
performed using PRISM software (GraphPad Software Inc., La Jolla, CA, USA,).

\section{Results}

Effects of Jawoongo on a DNCB-induced mouse model of AD

We investigated the effects of Jawoongo on DNCB-induced AD-like symptoms. We found that skin thickness increased following application of DNCB $(2.06 \pm 0.12 \mathrm{~mm})$ compared to no treatment $(0.57 \pm 0.03 \mathrm{~mm})$, and this increase was inhibited by both Jawoongo $(1.56 \pm 0.21 \mathrm{~mm})$ and tacrolimus $(1.25 \pm 0.18 \mathrm{~mm})$ treatment (Fig. 2a). In addition, we monitored the body weights and food intake of the mice throughout the study and observed no significant changes, suggesting that Jawoongo did not produce any toxic effects on the mice (Additional file 1: Figure S1A and B). H \& E

a

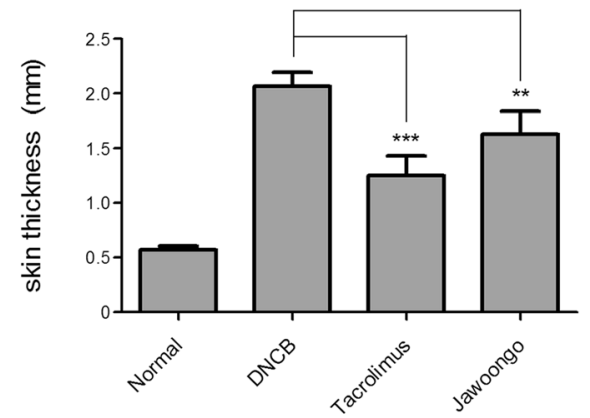

\begin{tabular}{lccc} 
& & & $(\mathrm{mm})$ \\
\hline Normal & DNCB & Tacrolimus & Jawoongo \\
\hline $0.57 \pm 0.03$ & $2.06 \pm 0.12$ & $1.25 \pm 0.18$ & $1.56 \pm 0.21$ \\
\hline
\end{tabular}

b

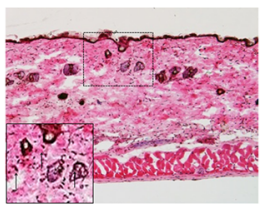

Normal

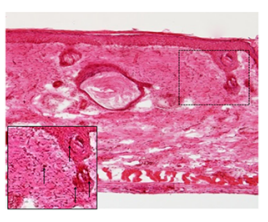

Tacrolimus

C

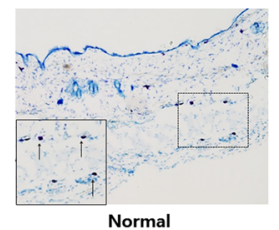

Normal

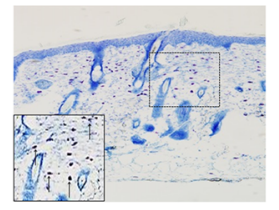

Tacrolimus

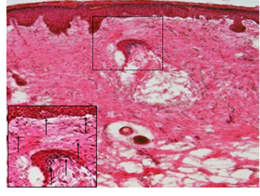

DNCB

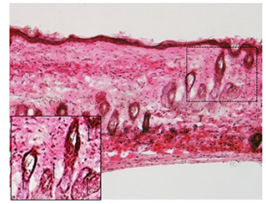

Jawoongo
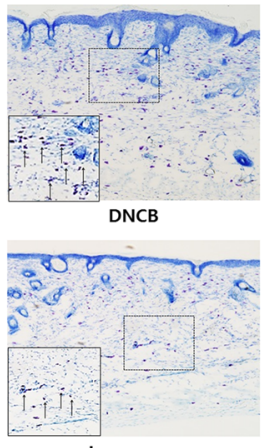
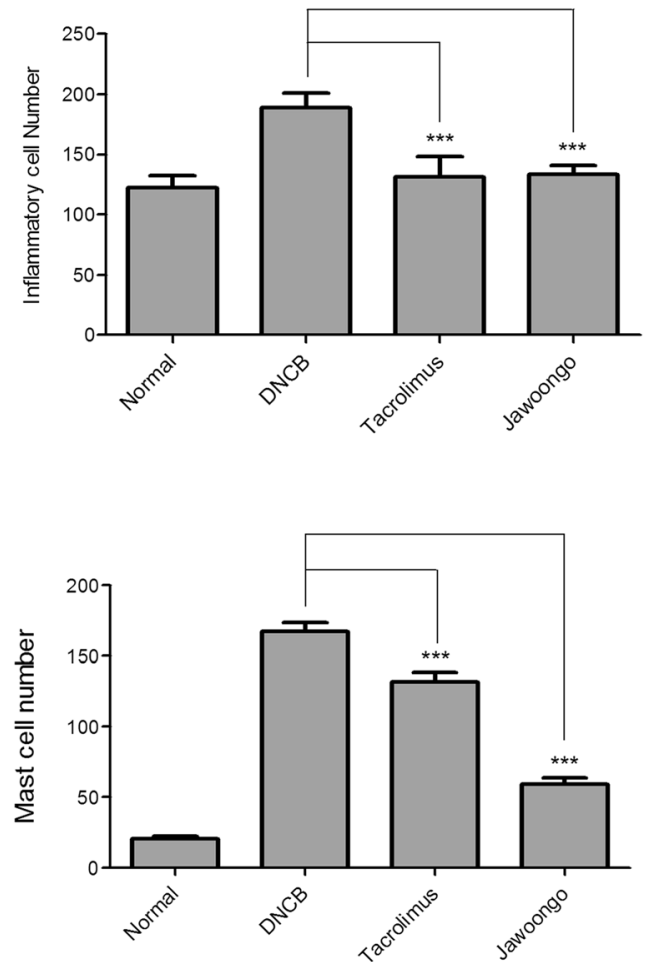

Fig. 2 Effects of Jawoongo on the skin of mice with DNCB-induced AD. Skin thickness in mice with DNCB-induced AD that were treated with Jawoongo (a). Jawoongo reduced the infiltration of inflammatory cells into the skin. Skin sections were stained with hematoxylin and eosin (b). Arrows indicate inflammatory cells. Jawoongo reduced the infiltration of mast cells into the skin. Skin sections were stained with toluidine blue (c). Arrows indicate inflammatory cells. The sections were evaluated under a microscope at an original magnification of $200 \times$. The data were presented as mean \pm SEMs ( $n=8$ mice/group). ${ }^{*} P<0.05$, ${ }^{* *} P<0.01$ and ${ }^{* * *} P<0.001$ as compared to DNCB-stimulated group, respectively 
staining was performed to examine whether Jawoongo reduces the infiltration of inflammatory cells into the skin. The number of inflammatory cells in the mice with DNCB-induced AD lesions was higher than that in the normal mice and decreased following treatment with Jawoongo or tacrolimus (Fig. 2b, left panel). The bar graph indicates the average number of cells counted from a random field of view (Fig. 3b, right panel). Moreover, toluidine blue staining was used to examine whether Jawoongo reduces mast cell infiltration into the skin. There was greater mast cell infiltration in the skin of the mice with DNCB-induced AD lesions than that of the normal mice. Treatment with Jawoongo or tacrolimus decreased the infiltration of mast cells into the skin (Fig. 2c, left panel). The bar graph indicates the average number of cells counted from a random field of view (Fig. 2c, right panel).

\section{Jawoongo treatment lowered the number of WBCs in the blood of mice}

Application of DNCB increased both the total number of white blood cells (WBCs) and the number of each WBC subtype, including neutrophils, basophils, eosinophils, monocytes, and lymphocytes, in the serum of the mice. Importantly, treatment with Jawoongo or tacrolimus lowered the increased number of WBCs, indicating that Jawoongo and tacrolimus suppress inflammation by decreasing the number of WBCs in the blood (Fig. 3a, b, c, d, e and f).
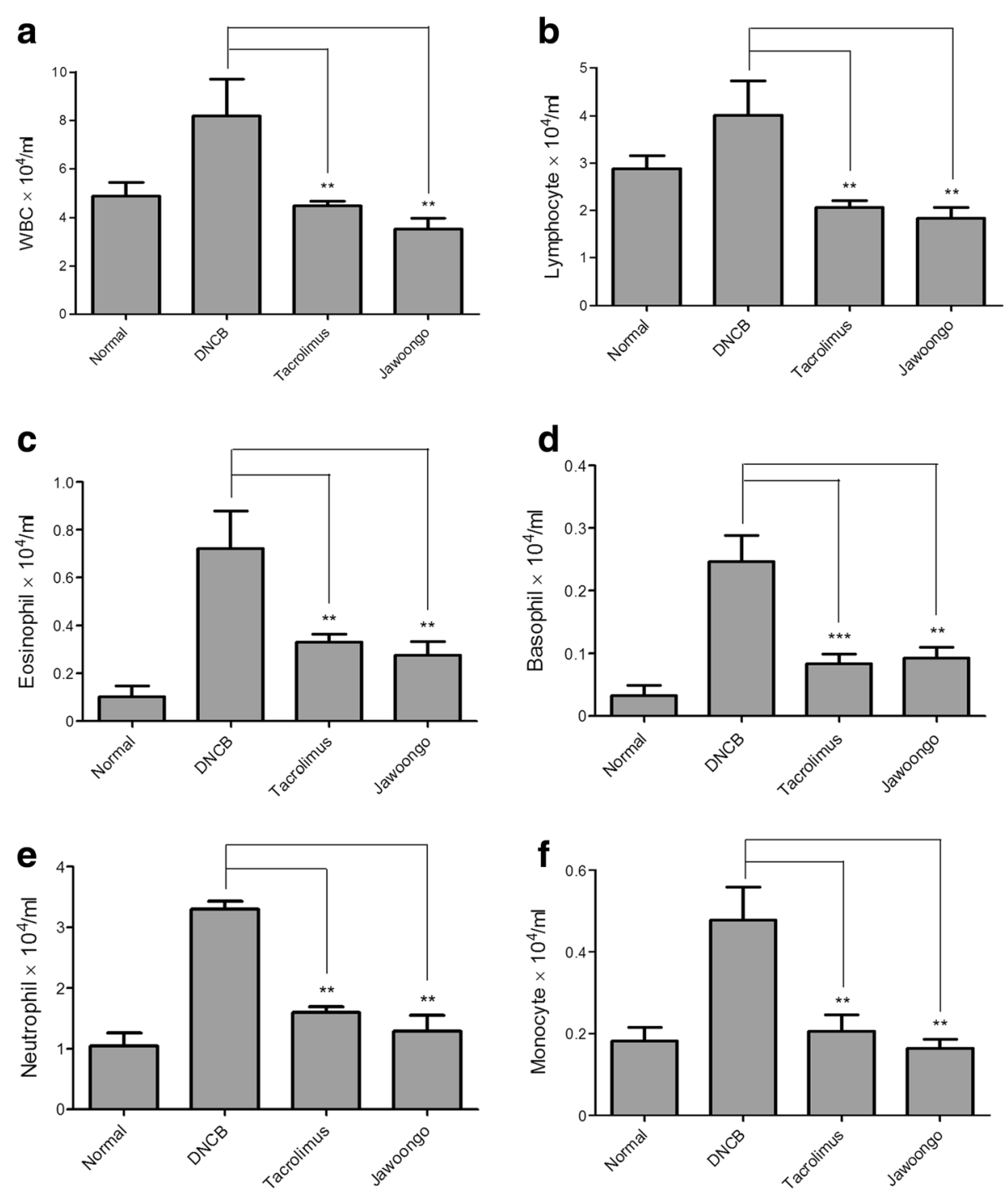

Fig. 3 Jawoongo reduced leukocyte numbers in the blood. Blood samples were analyzed using a HEMAVET 950 hematological analyzer. The data were presented as mean \pm SEMs ( $n=8$ mice/group). ${ }^{*} P<0.05$, ${ }^{*} P<0.01$ and ${ }^{* * *} P<0.001$ as compared to DNCB-stimulated group, respectively 
Jawoongo treatment reduced the serum levels of $\lg \mathrm{E}$, IL6, IL-10 and IL-12 in mice

We next measured proinflammatory cytokine levels by ELISA. We found that Jawoongo treatment reduced the serum levels of IgE, IL-6, IL-10 and IL-12 whose expression was induced after DNCB application. Tacrolimus treatment increased the serum levels of IgE (Fig. 4a, b, c and d).

\section{Jawoongo treatment down-regulated mRNA expression} of IL-2, IL-4, IL-13, and TNF- $\alpha$ in mouse skin

RT-PCR analysis of RNA extracted from mouse skin revealed that $\mathrm{DNCB}$ increased the levels of $\mathrm{AD}$-associated cytokines such as IL-2, IL-4, IL-13 and TNF- $\alpha$ when applied to skin, and subsequent treatment with Jawoongo or tacrolimus suppressed the increased cytokine levels (Fig. 5a, b, c and d).

\section{Jawoongo treatment reduced the number of CD4+ cells in skin}

We performed immunocytochemistry to examine whether Jawoongo treatment can reduce the level of CD4+ in skin. The level of CD4+ in the mice with DNCB-induced AD lesions was higher than that in the normal mice.
Additional treatment with Jawoongo or tacrolimus decreased the number of CD4+ cells (Fig. 6).

\section{Jawoongo inhibited agonist-induced cytokine production in HMC-1 cells}

Based on the observation that Jawoongo inhibited $\mathrm{AD}$-associated cytokine production in mice, we next investigated whether Jawoongo affects cytokine expression in human mast cell line 1 (HMC-1) cells. To accomplish this, HMC-1 cells were stimulated with ionomycin and PMA before treatment with varying concentrations of Jawoongo. RT-PCR analysis showed that Jawoongo dose-dependently suppressed the IL-4, IL-13 and TSLP mRNA expression that was induced by treatment with ionomycin and PMA (Fig. 7a). Moreover, Western blot analysis indicated that Jawoongo significantly reduced agonist-stimulated Erk, JNK, NF-kB and COX-2 protein expression in a dose-dependent manner (Fig. 7b). We also demonstrated that Jawoongo inhibited agonist-stimulated IL-4, IL-6, and IL-13 secretion, as determined by ELISA (Fig. 7c). No significant effect on cell viability was observed in HMC-1 cells treated with Jawoongo alone or in combination with ionomycin and PMA (Additional file 2: Figure S2A).

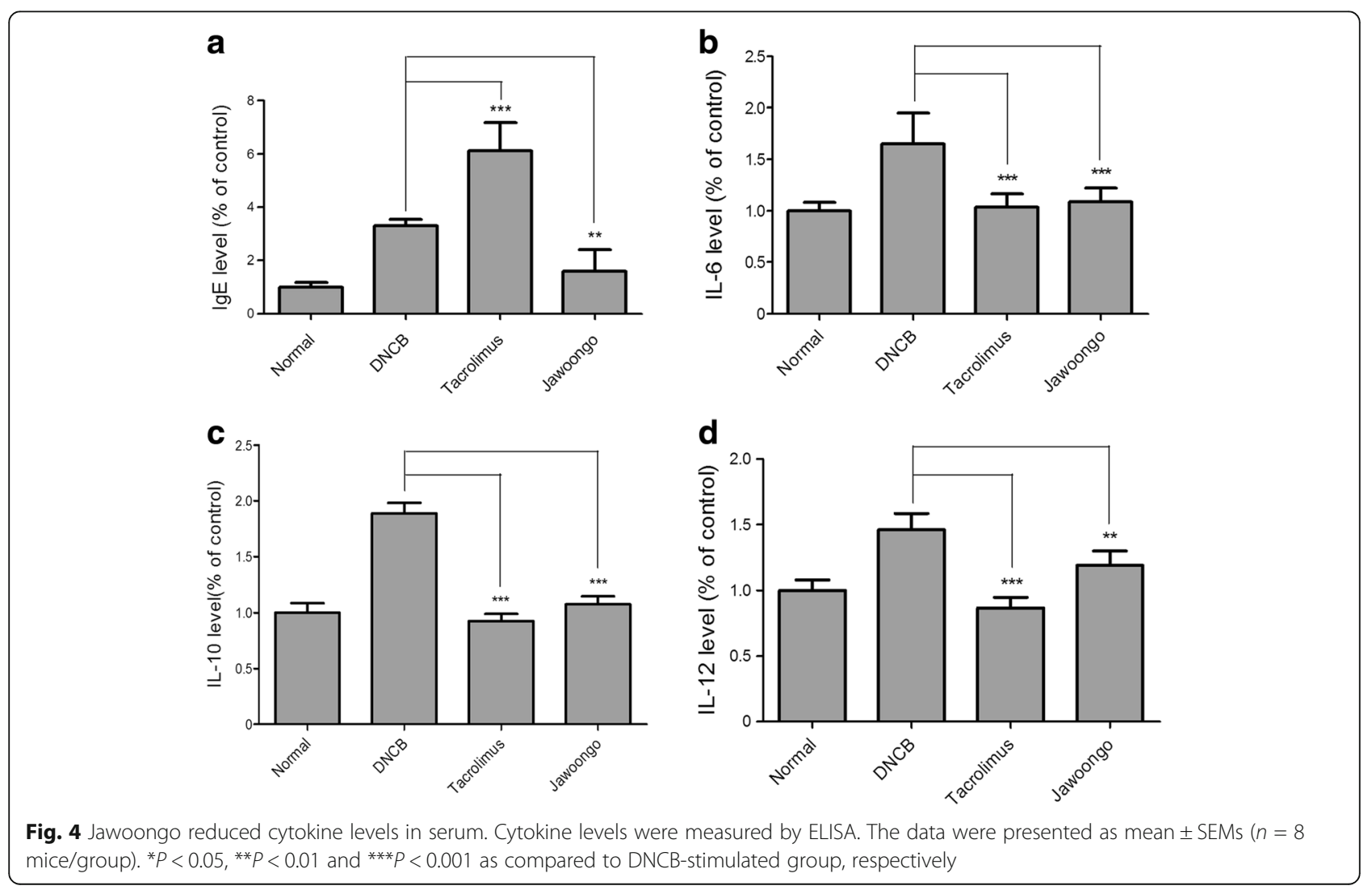



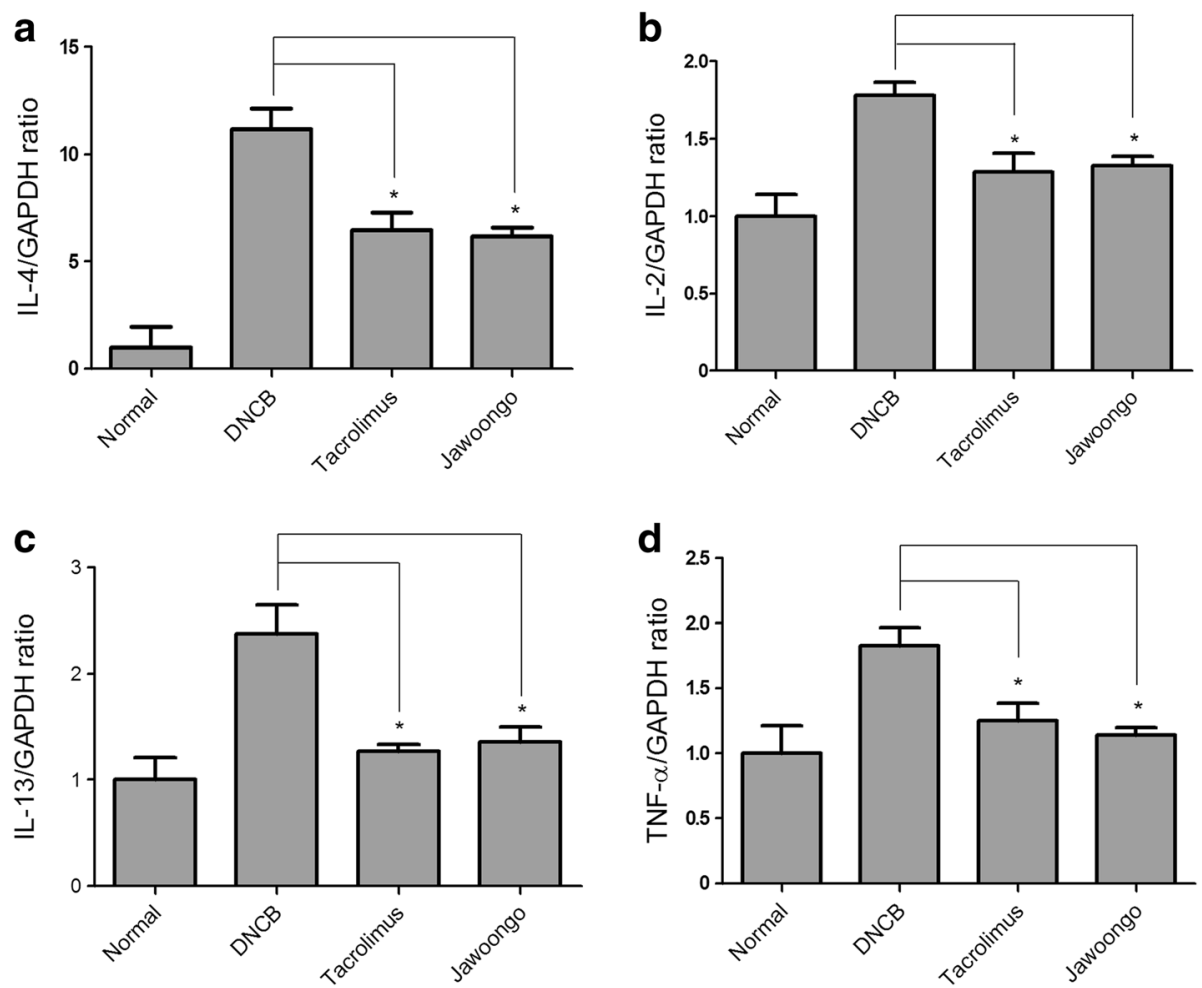

Fig. 5 Effects of Jawoongo on cytokine mRNA expression in mouse skin tissue. IL-2, IL-4, IL-13 and TNF-a mRNA expression was measured by RT-PCR, shown in (a), (b), (c), and (d), respectively, in mouse skin tissue. The data were presented as mean \pm SEMs $\left(n=8\right.$ mice/group). ${ }^{*} P<0.05$, ${ }^{*} P<0.01$ and ${ }^{* *} P<0.001$ as compared to DNCB-stimulated group, respectively

\section{Jawoongo inhibited LPS-induced inflammatory responses in RAW264.7 cells}

Because NO plays an important role in allergic responses, we next examined the effects of Jawoongo on NO production and inducible nitric oxide synthase (iNOS) mRNA expression in the murine RAW264.7 macrophage cell line. As shown in Fig. 8a and b, Jawoongo reduced LPS-induced NO production and iNOS mRNA expression in a dose-dependent manner. Jawoongo also decreased LPS-induced increases in mRNA and protein expression of inflammation-related genes, such as tumor necrosis factor- $\alpha$ (TNF- $\alpha$ ) and COX-2. Moreover, Jawoongo had an inhibitory effect on ERK and JNK activation in relation to various inflammatory responses (Fig. 8c). When using a low concentration of Jawoongo $(\sim 100 \mathrm{~g} / \mathrm{ml})$, no significant effect on RAW264.7 cell viability was observed (Additional file 2: Figure S2B).

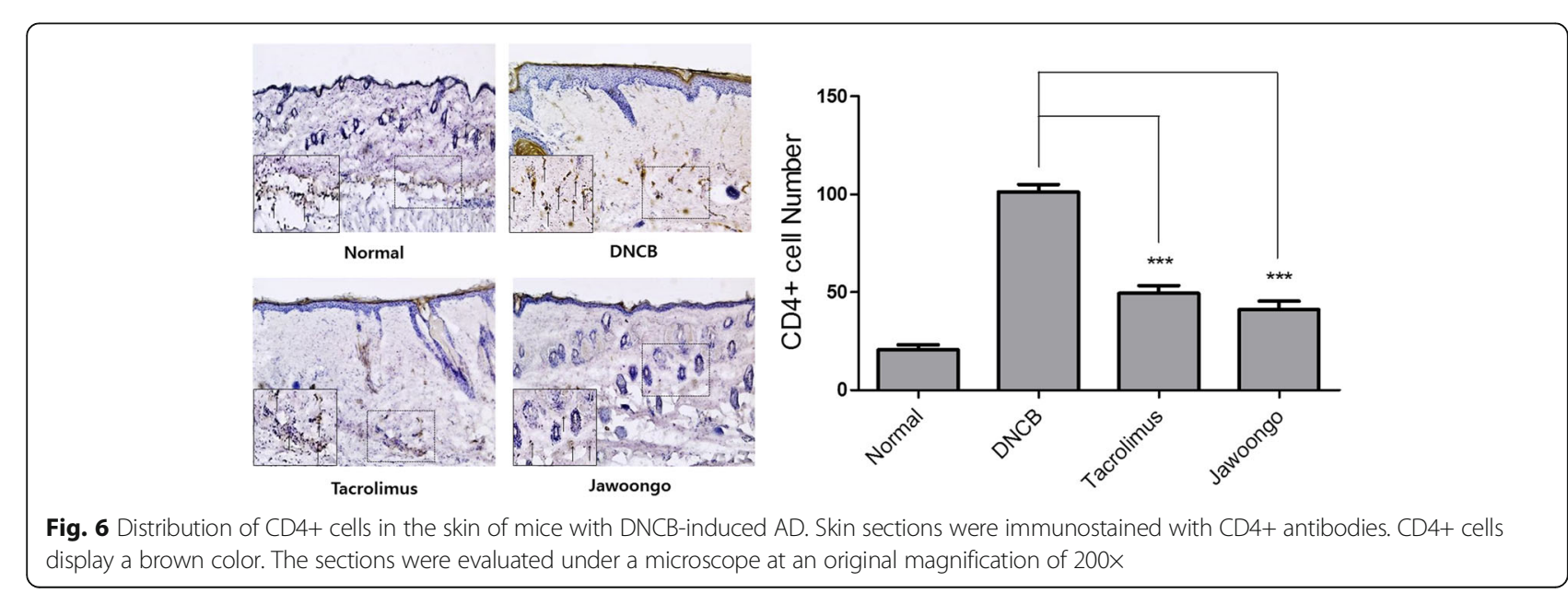



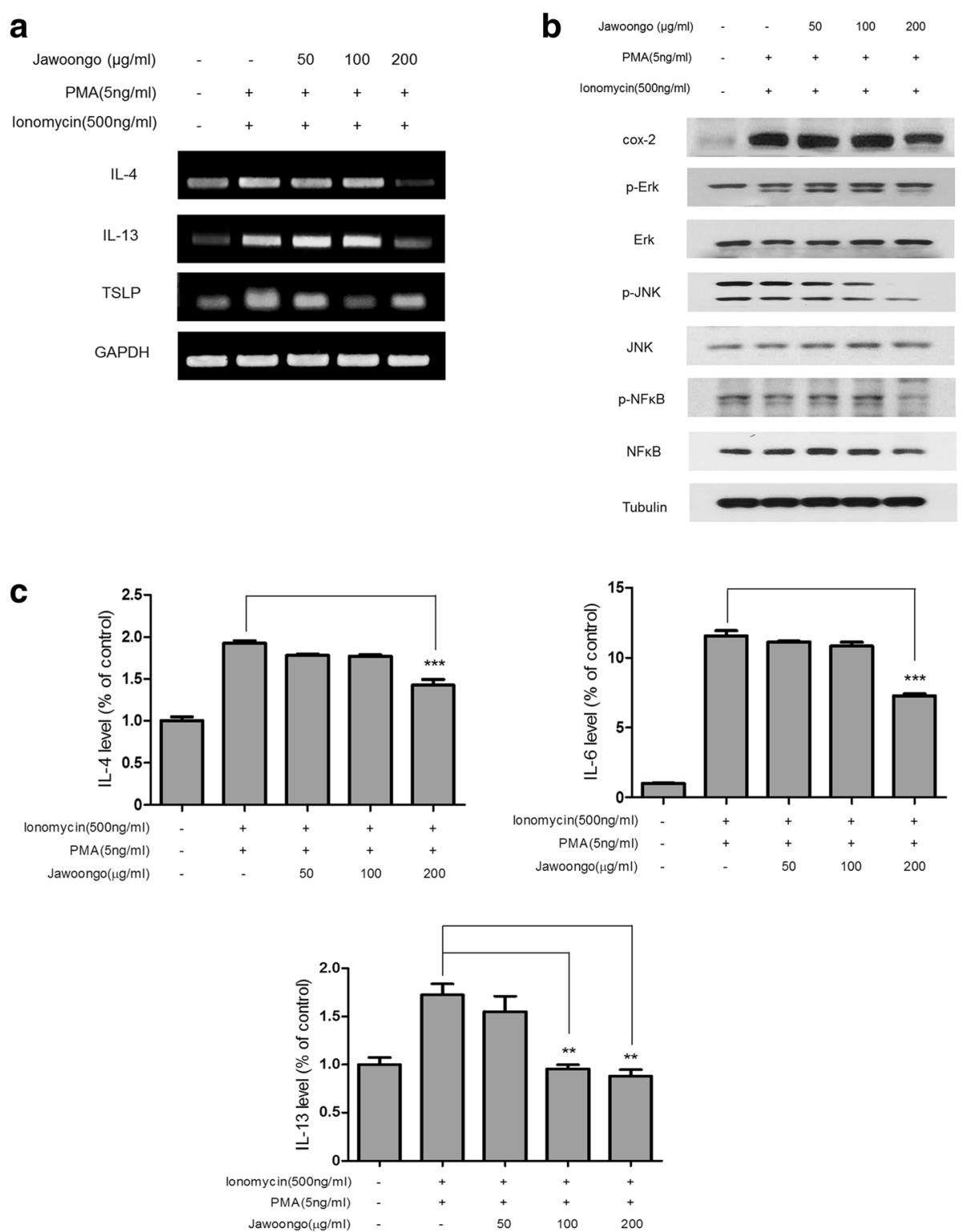

Fig. 7 Effects of Jawoongo on cytokine expression in HMC-1 cells. HMC-1 cells were stimulated with ionomycin (500 ng/ml) and PMA (5 ng/ml) and then treated with different concentrations of Jawoongo $(50-200 \mu \mathrm{g} / \mathrm{ml})$ for $24 \mathrm{~h}$. IL-4, IL-13 and TSLP mRNA expression was measured by RT-PCR (a). Whole cell lysates were analyzed by Western blotting (b). The culture medium of the cells was harvested, and IL-4, IL-6 and IL-13 cytokine levels were measured by ELISA (c). The data were presented as mean \pm SEMs ( $n=8$ mice/group). ${ }^{*} P<0.05,{ }^{* *} P<0.01$ and ${ }^{* * *} P<0.001$ as compared to lonomycin and PMA-stimulated group, respectively

\section{Jawoongo inhibited LPS-induced inflammatory responses in isolated Splenocytes}

We further tested Jawoongo's anti-inflammatory activities in splenocytes isolated from mice. Similar to HMC-1 and RAW264.7 cells, Jawoongo treatment reduced the mRNA levels of proinflammatory cytokines, including IL-4, IL-6, and TNF- $\alpha$ in LPS-stimulated splenocytes (Fig. 9a). Dose-dependent inhibition of IL- 6 and TNF- $\alpha$ secretion by Jawoongo was also observed (Fig. 9b). Finally, Western blot analysis demonstrated that treatment with a high dose of Jawoongo decreased COX-2 and iNOS levels and NF-KB activity in LPS-induced splenocytes (Fig. 9c). At a concentration of $\sim 200 \mathrm{~g} / \mathrm{ml}$, as was used in these experiments, Jawoongo showed no significant toxic effects on splenocytes (Additional file 2: Figure S2C).

\section{Decursin is an Indicator molecule for Jawoongo}

Liquid chromatography-mass spectrometry was used to measure the retention time of decursin. Chromatograms were acquired at $215 \mathrm{~nm}$ on an HPLC by UV detection 


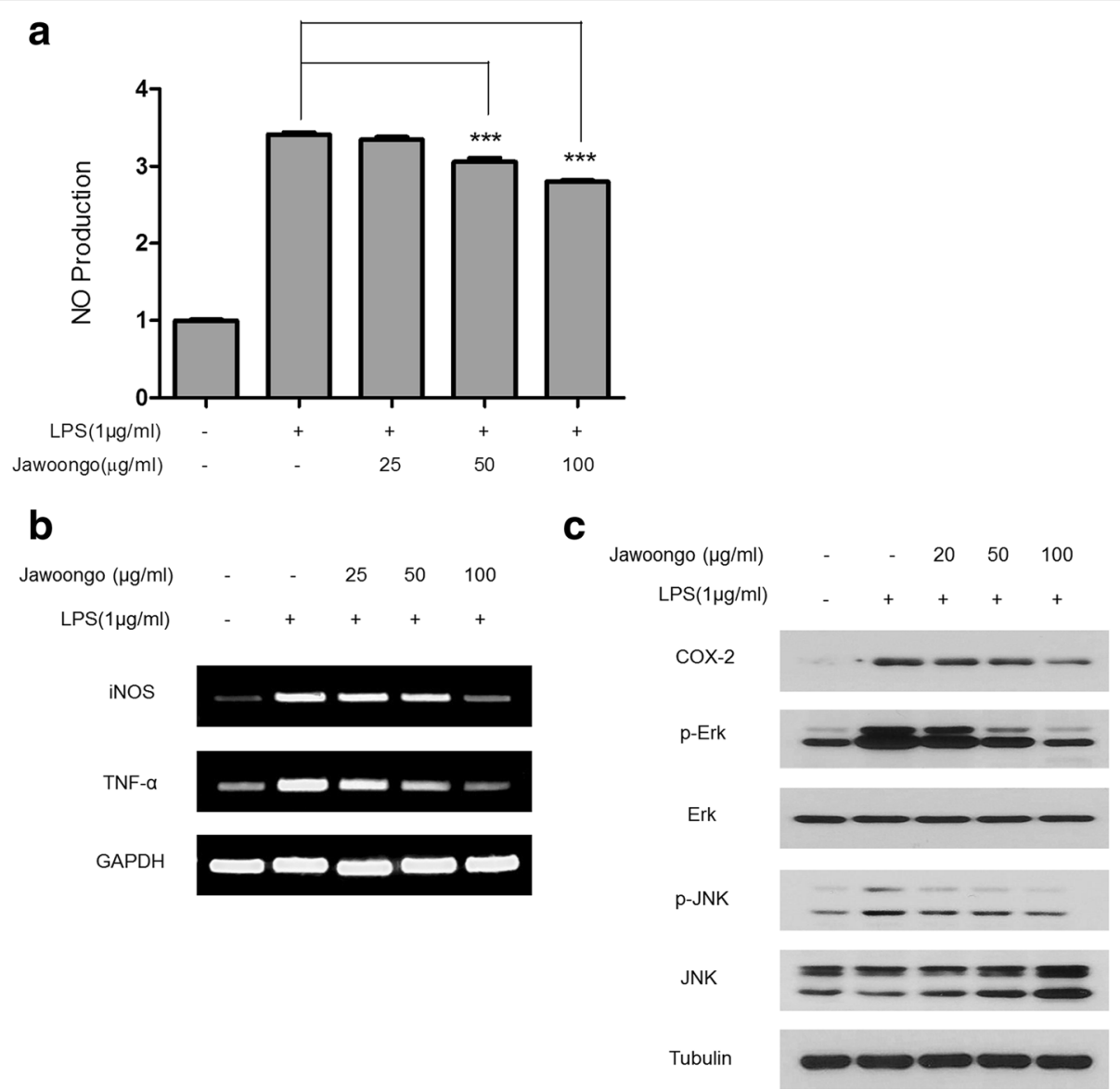

Fig. 8 Effects of Jawoongo on NO production in RAW264.7 cells. RAW264.7 cells were stimulated with LPS (1 mg/ml) and then treated with different concentrations of Jawoongo $(25-100 \mu \mathrm{g} / \mathrm{ml})$ for $24 \mathrm{~h}$. NO production was measured using the Griess reagent system (a). iNOS and TNF-a mRNA expression was measured by RT-PCR (b). Whole cell lysates were analyzed by Western blotting (c). The data were presented as mean \pm SEMs ( $n=8$ mice/group). ${ }^{*} P<0.05,{ }^{* *} P<0.01$ and ${ }^{* *} P<0.001$ as compared to LPS-stimulated group, respectively

(Fig. 10a), and the retention time of decursin was $53.028 \mathrm{~min}$ (Fig. 10b).

\section{Discussion}

$\mathrm{AD}$ is a common pruritic and chronically relapsing inflammatory skin disease. Affecting approximately $10-20 \%$ of children and $1-3 \%$ of adults worldwide [39], AD is a major global public health problem. Additionally, the incidence of $\mathrm{AD}$ has steadily increased every year [40].

Several mouse models have been developed to evaluate drugs for the treatment of AD. A DNCB-patch model using BALB/c mice has been proposed as a suitable representative of human $\mathrm{AD}$ because mice treated with DNCB show symptoms similar to human $\mathrm{AD}$, including epidermal hyperplasia, dermal mast cell infiltration, and elevated serum IgE levels [41]. Activated mast cells release inflammatory mediators such as histamines, cytokines and chemokines [42, 43]. In this study, we investigated the anti-AD effects of Jawoongo using DNCB-treated BALB/c mice. We found that topical application of Jawoongo strongly suppressed DNCB-induced AD-like lesions and reduced skin thickness, CD4 levels and mast cell infiltration in sensitized skin. We observed that Jawoongo suppresses skin inflammation by inhibiting various DNCB-stimulated inflammatory responses.

Until now, the exact pathogenesis of AD has remained unclear. However, Th1 and Th2 cytokines play an important role in the etiology of AD. In particular, Th2 cytokines are important mediators of AD development [44]. CD4+ T cells are key factors implicated in the pathogenesis of $\mathrm{AD}$, and skin infiltration of $\mathrm{CD} 4+\mathrm{T}$ cells is known to increase in severe AD cases [45].

Therefore, we investigated cytokines related to Th2 in an in vivo model. Jawoongo treatment reduced the 
a

$\begin{array}{rcccccc}\text { Jawoongo }(\mu \mathrm{g} / \mathrm{ml}) & - & - & 25 & 50 & 100 & 200 \\ \operatorname{LPS}(1 \mu \mathrm{g} / \mathrm{ml}) & - & + & + & + & + & +\end{array}$

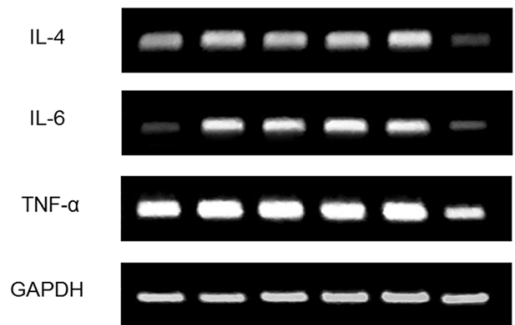

b
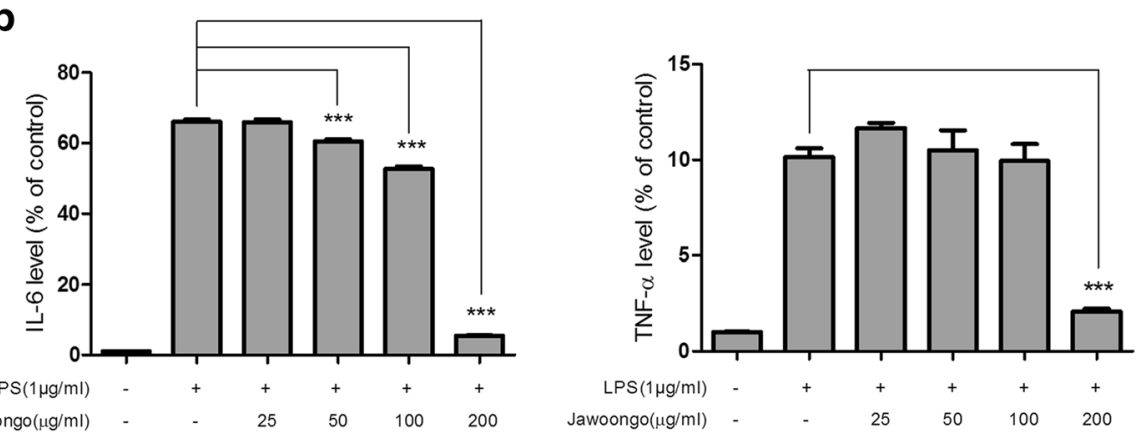

C

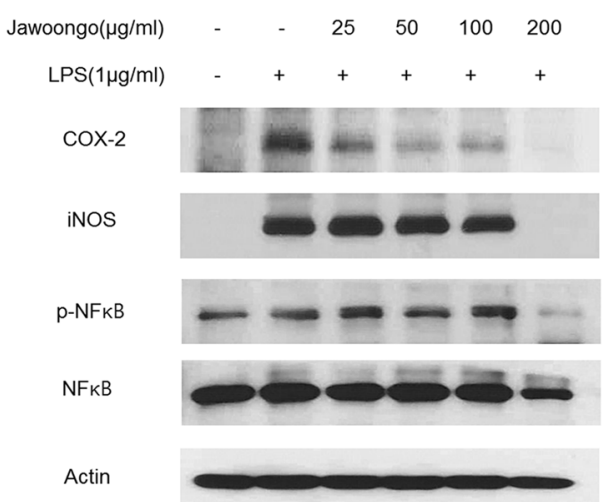

Fig. 9 Effects of Jawoongo on cytokine expression in splenocytes. Splenocytes were stimulated with $L P S(1 \mu \mathrm{g} / \mathrm{ml})$ and then treated with different concentrations of Jawoongo (25-200 $\mathrm{mg} / \mathrm{ml})$ for $24 \mathrm{~h}$. IL-4, IL-6 and TNF-a mRNA expression was measured by RT-PCR (a). The culture medium of the cells was harvested, and IL-6 and TNF-a cytokine levels were measured by ELISA (b). Whole cell lysates were analyzed by Western blotting $(\mathbf{c})$. The data were presented as mean \pm SEMs $\left(n=8\right.$ mice/group). ${ }^{*} P<0.05,{ }^{* *} P<0.01$ and ${ }^{* * *} P<0.001$ as compared to LPS-stimulated group, respectively

increased serum levels of IgE, IL-6, IL-10 and IL-12 induced by DNCB treatment In fact, it was reported that IL-12 was increased by DNCB [46, 47], and this increase was suppressed by Jawoongo as expected. We also found that Jawoongo reduced DNCB-stimulated increases in eosinophil, neutrophil, monocyte, basophil, lymphocyte and WBC numbers and in IL-4, IL-13 and TNF- $\alpha$ mRNA expression. These results suggest that Jawoongo decreased the number of CD4+ cells entering the skin. Of note, Jawoongo and tacrolimus, which was used as a positive control in this study, showed similar effects on AD-like skin lesions, but Jawoongo exhibited more favorable effects than tacrolimus in some aspects, such as in decreased mast cell recruitment and serum IgE levels.

To improve our understanding of Jawoongo's actions at the cellular level, we evaluated the effects of Jawoongo on several types of innate immune cell, including human mast cells (HMC-1), murine macrophage RAW264.7 cells, and splenocytes isolated from mice. 

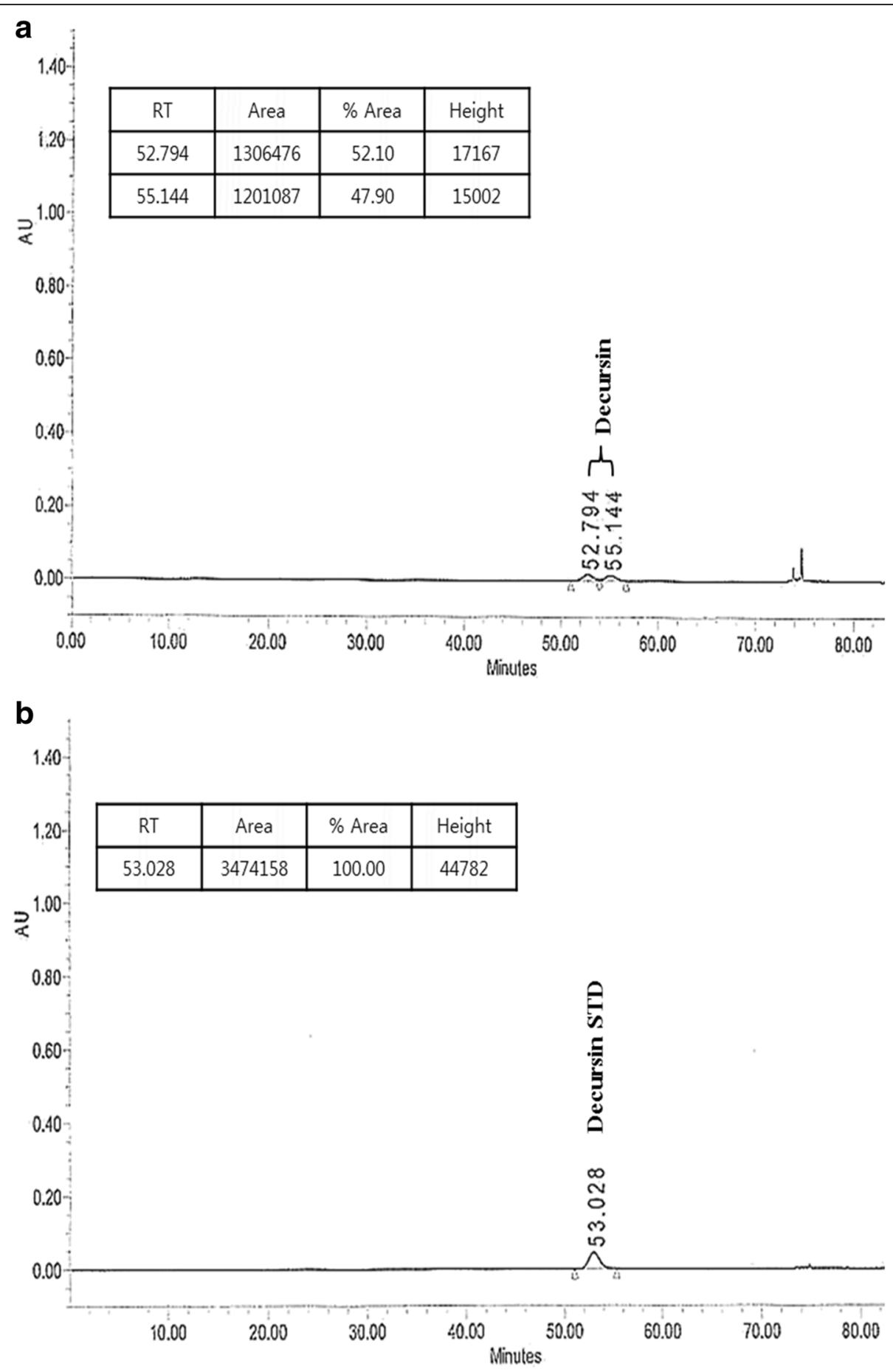

Fig. 10 LC-MS chromatogram. a Identification of decursin in Jawoongo. b Mass spectrum peak at 53.028 min

Inflammation causes cells to respond to stimulation by releasing various cytokines and by increasing COX-2 expression. Therefore, COX-2 expression can be measured to evaluate anti-inflammatory effects $[48,49]$. In the present study, Jawoongo treatment suppressed $\mathrm{AD}$-associated cytokine production, such as IL-4, Erk,
JNK, p-NF-kB and COX-2 expression, in HMC-1 cells. iNOS produces $\mathrm{NO}$ after it is activated by various cytokines. Inflammatory and immune responses lead to vasodilation, erythema and edema in response to increasing NO levels. Excessive NO aggravates the inflammatory response due to the immune-regulatory 


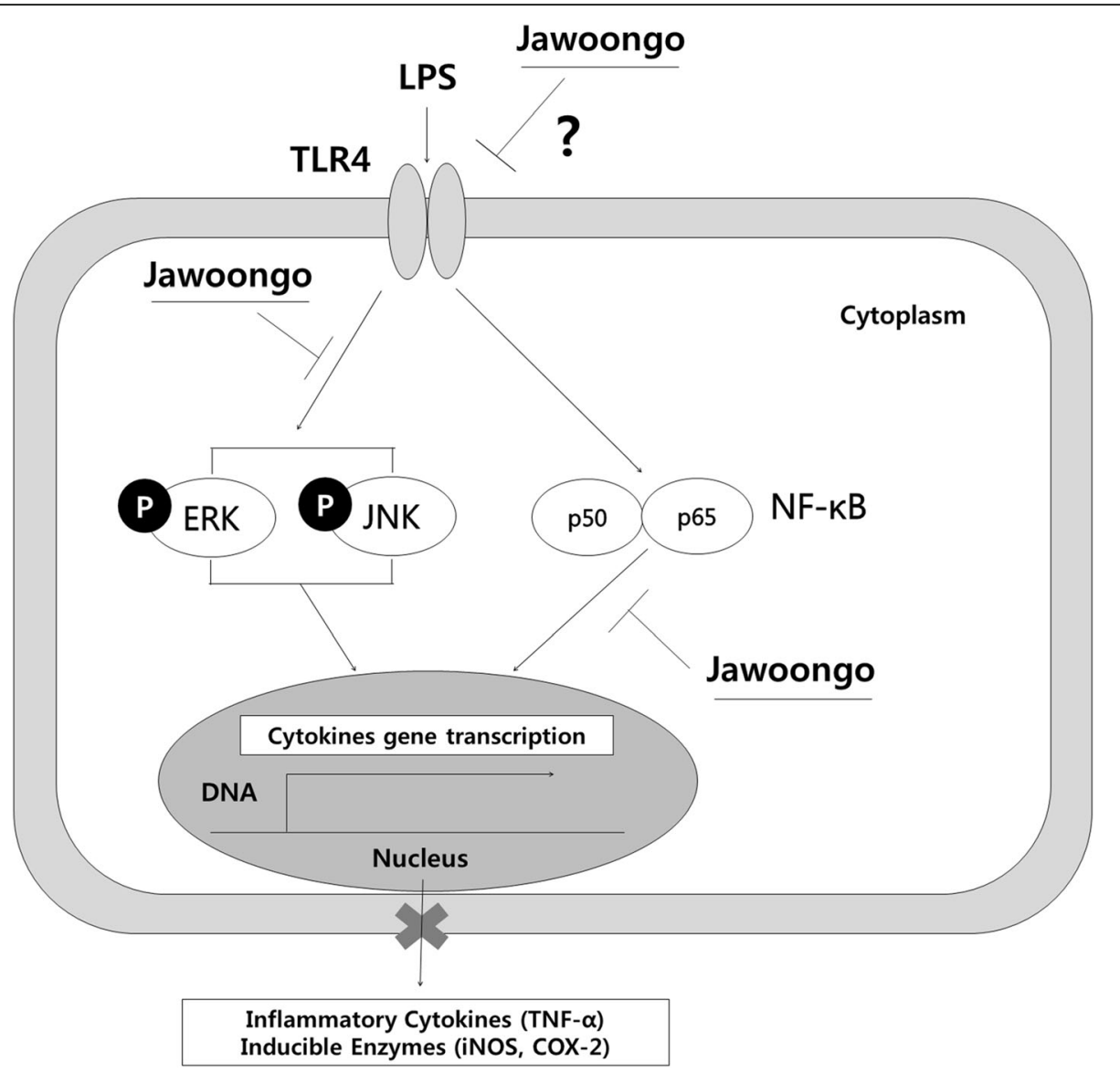

Fig. 11 Pathway diagram of the mechanism of histamine inhibition of ERK, JNK and NF-kB activation. RAW264.7 cells and Splenocyte activated with a LPS agonist activated the MEK/ERK MAPK signaling and NF-KB signaling cascade to induce production of TNF. Jawoongo inhibited MEK ERK and NF-KB activation and suppressed production of TNF

role of NO [50, 51]. Macrophages contain several factors that regulate cytokine and chemokine secretion in AD. Therefore, macrophages have an important role in both the acute and chronic inflammation associated with AD [52-54]. Macrophages are involved in the initiation and maintenance of acute and chronic inflammatory responses [55]. Treatment of murine macrophage RAW264.7 cells with Jawoongo suppressed LPS-stimulated NO production, reduced iNOS and TNF- $\alpha$ mRNA levels, and decreased ERK and JNK activation. We also found that Jawoongo treatment reduced IL-4, IL- 6 and TNF- $\alpha$ mRNA levels; COX-2 and iNOS protein levels; and NFKB activity in LPS-induced splenocytes. It appears that high concentrations of Jawoongo are required to mediate an effect in vitro. Because both MAP kinase and NFKB pathways are implicated in AD, Jawoongo appears to inhibit both pathways (Fig. 11). Taken together, our results suggest that Jawoongo regulates proinflammatory cytokine production in several types of immune cell, thereby suppressing the AD-like symptoms caused by DNCB.

\section{Conclusions}

Our present study demonstrates that Jawoongo treatment suppresses DNCB-induced AD symptoms by downregulating serum IgE levels and the production of several inflammatory cytokines. In addition, our data indicate that Jawoongo treatment inhibits cytokine expression and activation of the NF-kB and MAPK pathways in several types of immune cell. Taken together, our results suggest that Jawoongo might be a useful candidate drug for the treatment of $\mathrm{AD}$.

\section{Additional files}

Additional file 1: Figure S1. Changes in body weight (A) and food intake (B) in DNCB-induced AD mice during treatment with Jawoongo. Values are expressed as the mean \pm SEMs $(n=8)$. (TIF $4580 \mathrm{~kb}$ )

Additional file 2: Figure S2. Effects of Jawoongo on cell viability in various cell lines. HMC-1 cells were treated with the combination of ionomycin $(500 \mathrm{ng} / \mathrm{ml})$ and PMA $(5 \mathrm{ng} / \mathrm{ml})$ with varying concentrations of DMSO and Jawoongo $(5-500 \mu \mathrm{g} / \mathrm{ml})$ for $24 \mathrm{~h}(\mathrm{~A})$. RAW264.7 cells (B) and splenocytes (C) were treated with the combination of LPS (1 mg/ml) and varying concentrations of DMSO and Jawoongo $(5-500 \mu \mathrm{g} / \mathrm{ml})$ for $24 \mathrm{~h}$. 
Cell viability was measured using an MTS assay. The data were presented as mean \pm SEMs of three independent experiments. ${ }^{*} P<0.05,{ }^{* *} P<0.01$ and ${ }^{* * *} P<0.001$. (TIF $18563 \mathrm{~kb}$ )

\section{Abbreviations}

AD: Atopic dermatitis; AGN: Angelica gigas Nakai; BSA: Bovine serum albumin; DAB: Diaminobenzidine; DNCB: 2,4-dinitrochlorobenzene; HMC1: Human mast cells; IgE: Immunoglobulin E; iNOS: Inducible nitric oxide synthase; MTS: 3-(4,5-dimethylthiazol-2-yl)-5-(3-carboxymethoxyphenyl)-2-(4sulfophenyl)-2H-tetrazolium; NO: Nitric oxide; OCT: Optical cutting temperature; PGD2: Prostaglandin D2; PMA: Phorbol-12-Myristate-13-Acetate; TB: Toluidine blue; Th2: T-helper 2; TNF-a: Tumor necrosis factor-a; TSLP: Thymic stromal lymphopoietin; WBCs: White blood cells; WST: Tetrazolium salt

\section{Acknowledgements}

We thank our colleagues from the Laboratory of Prevention medicine for technique assistance and useful discussions.

\section{Funding}

This research was supported by a grant from the Korean Medicine R\&D Project of the Ministry of Health and Welfare (HI12C1889 and HI13C0530).

\section{Availability of data and materials}

All data and materials are contained and described within the manuscript.

\section{Authors' contributions}

JMK carried out the experiment and drafting of manuscript. SHH, SRK, HC, HIK, DUK and SMO revised the research and manuscript and assisted in the research work. HSS, TYK and YCS guided the research, revised and submitted the manuscript. CC and SGK designed, supervised the experiments and corrected the manuscript. All the authors read and approved the final manuscript.

\section{Ethics approval and consent to participate}

Animal experiments were approved by Kyung Hee university institutional animal care of use committee (Approval No. KHUASP(SE)-12-014).

\section{Consent for publication}

Not applicable.

\section{Competing interests}

The authors declare that they have no competing interests.

\section{Publisher's Note}

Springer Nature remains neutral with regard to jurisdictional claims in published maps and institutional affiliations.

\section{Author details}

'Department of Science in Korean Medicine, Graduate School, Kyung Hee University, Kyungheedae-ro 26, Dongdaemun-gu, Seoul 02447, Republic of Korea. ${ }^{2}$ Department of Preventive Medicine, College of Korean Medicine, Kyung Hee University, Kyungheedae-ro 26, Dongdaemun-gu, Seoul 02447, South Korea.

Received: 21 December 2017 Accepted: 6 July 2018

Published online: 13 July 2018

\section{References}

1. Kaiko GE, Phipps S, Angkasekwinai P, Dong C, Foster PS. NK cell deficiency predisposes to viral-induced Th2-type allergic inflammation via epithelialderived IL-25. J Immunol. 2010;185(8):4681-90.

2. Yang JQ, Liu H, Diaz-Meco MT, Moscat J. NBR1 is a new PB1 signalling adapter in Th2 differentiation and allergic airway inflammation in vivo. EMBO J. 2010;29(19):3421-33

3. Shirinbak S, Taher YA, Maazi H, Gras R, van Esch BC, Henricks PA, Samsom JN, Verbeek JS, Lambrecht BN, van Oosterhout AJ, et al. Suppression of Th2driven airway inflammation by allergen immunotherapy is independent of $B$ cell and Ig responses in mice. J Immunol. 2010;185(7):3857-65.
4. Grewe M, Bruijnzeel-Koomen CA, Schopf E, Thepen T, LangeveldWildschut AG, Ruzicka T, Krutmann J. A role for Th1 and Th2 cells in the immunopathogenesis of atopic dermatitis. Immunol Today. 1998; 19(8):359-61.

5. Torii M, Wang L, Ma N, Saito K, Hori T, Sato-Ueshima M, Koyama Y, Nishikawa H, Katayama N, Mizoguchi A, et al. Thioredoxin suppresses airway inflammation independently of systemic Th1/Th2 immune modulation. Eur J Immunol. 2010;40(3):787-96.

6. Mabalirajan U, Agrawal A, Ghosh B. Comment on "Ym1/2 promotes Th2 cytokine expression by inhibiting 12/15(S)-lipoxygenase: identification of a novel pathway for regulating allergic inflammation". J Immunol. 2009; 183(10):6039. author reply 6039-6040

7. Kitajima M, Iwamura C, Miki-Hosokawa T, Shinoda K, Endo Y, Watanabe Y, Shinnakasu R, Hosokawa H, Hashimoto K, Motohashi S, et al. Enhanced Th2 cell differentiation and allergen-induced airway inflammation in Zfp35deficient mice. J Immunol. 2009;183(8):5388-96.

8. Akitake R, Nakase H, Tamaoki M, Ueno S, Mikami S, Chiba T. Modulation of Th1/Th2 balance by infliximab rescues postoperative occurrence of smallintestinal inflammation associated with ulcerative colitis. Dig Dis Sci. 2010; 55(6):1781-4

9. Dubois A, Deruytter N, Adams B, Kanda A, Delbauve S, Fleury S, Torres D, Francois A, Petein M, Goldman M, et al. Regulation of Th2 responses and allergic inflammation through bystander activation of CD8+ T lymphocytes in early life. J Immunol. 2010;185(2):884-91.

10. Girtsman T, Jaffar Z, Ferrini M, Shaw P, Roberts K. Natural Foxp3(+) regulatory $T$ cells inhibit Th2 polarization but are biased toward suppression of Th17-driven lung inflammation. J Leukoc Biol. 2010;88(3):537-46.

11. Jie Z, Jin M, Cai Y, Bai C, Shen Y, Yuan Z, Hu Y, Holgate S. The effects of Th2 cytokines on the expression of ADAM33 in allergen-induced chronic airway inflammation. Respir Physiol Neurobiol. 2009;168(3):289-94.

12. Perros F, Hoogsteden HC, Coyle AJ, Lambrecht BN, Hammad H. Blockade of CCR4 in a humanized model of asthma reveals a critical role for DC-derived CCL17 and CCL22 in attracting Th2 cells and inducing airway inflammation. Allergy. 2009;64(7):995-1002

13. Singh SP, Mishra NC, Rir-Sima-Ah J, Campen M, Kurup V, Razani-Boroujerdi S, Sopori ML. Maternal exposure to secondhand cigarette smoke primes the lung for induction of phosphodiesterase-4D5 isozyme and exacerbated Th2 responses: rolipram attenuates the airway hyperreactivity and muscarinic receptor expression but not lung inflammation and atopy. J Immunol. 2009; 183(3):2115-21.

14. Niu N, Laufer T, Homer RJ, Cohn L. Cutting edge: limiting MHC class II expression to dendritic cells alters the ability to develop Th2- dependent allergic airway inflammation. J Immunol. 2009;183(3):1523-7.

15. Park SK, Cho MK, Park HK, Lee KH, Lee SJ, Choi SH, Ock MS, Jeong HJ, Lee $\mathrm{MH}, \mathrm{Yu}$ HS. Macrophage migration inhibitory factor homologs of anisakis simplex suppress Th2 response in allergic airway inflammation model via CD4+CD25+Foxp3+ T cell recruitment. J Immunol. 2009;182(11):6907-14.

16. Min HJ, Won HY, Kim YC, Sung SH, Byun MR, Hwang JH, Hong JH, Hwang ES. Suppression of Th2-driven, allergen-induced airway inflammation by sauchinone. Biochem Biophys Res Commun. 2009;385(2):204-9.

17. Xia H, Cai SX, Tong WC, Luo LM, Yu HP. respiratory syncytial virus infection promotes the production of thymic stromal lymphopoietin and accelerates Th2 inflammation in mouse airway. Nan Fang Yi Ke Da Xue Xue Bao. 2009; 29(4):724-8

18. Cai $Y$, Kumar RK, Zhou J, Foster PS, Webb DC. Ym1/2 promotes Th2 cytokine expression by inhibiting 12/15(S)-lipoxygenase: identification of a novel pathway for regulating allergic inflammation. J Immunol. 2009; 182(9):5393-9.

19. Granot E, Yakobovich E, Bardenstein R. Tacrolimus immunosuppression - an association with asymptomatic eosinophilia and elevated total and specific IgE levels. Pediatr Transplant. 2006;10(6):690-3.

20. Tomi NS, Luger TA. The treatment of atopic dermatitis with topical immunomodulators. Clin Dermatol. 2003;21(3):215-24.

21. Kim IS, Kim DH, Yun CY, Lee JS. A (S)-(+)-decursin derivative, (S)-(+)-3-(3,4dihydroxy-phenyl)-acrylic acid 2,2-dimethyl-8-oxo-3,4-dihydro-2 $\mathrm{H}, 8 \mathrm{H}$ pyrano[3,2-g]-chromen-3-yl-ester, attenuates the development of atopic dermatitis-like lesions in NC/Nga mice. Mol Biol Rep. 2013;40(3):2541-8.

22. Li L, Li W, Jung SW, Lee YW, Kim YH. Protective effects of decursin and decursinol angelate against amyloid beta-protein-induced oxidative stress in the PC12 cell line: the role of Nrf2 and antioxidant enzymes. Biosci Biotechnol Biochem. 2011;75(3):434-42. 
23. Son SH, Park KK, Park SK, Kim YC, Kim YS, Lee SK, Chung WY. Decursin and decursinol from Angelica gigas inhibit the lung metastasis of murine colon carcinoma. Phytother Res. 2011;25(7):959-64.

24. Watanabe M, Kato J, Inoue I, Yoshimura N, Yoshida T, Mukoubayashi C, Deguchi H, Enomoto S, Ueda K, Maekita T, et al. Development of gastric cancer in nonatrophic stomach with highly active inflammation identified by serum levels of pepsinogen and helicobacter pylori antibody together with endoscopic rugal hyperplastic gastritis. Int J Cancer. 2012;131(11): 2632-42.

25. Qayyum T, McArdle PA, Lamb GW, Going JJ, Orange C, Seywright M, Horgan PG, Oades G, Aitchison MA, Edwards J. Prospective study of the role of inflammation in renal cancer. Urol Int. 2012;88(3):277-81.

26. Park BK, Park YC, Jung IC, Kim SH, Choi JJ, Do M, Kim SY, Jin M. Gamisasangja-tang suppresses pruritus and atopic skin inflammation in the NC/Nga murine model of atopic dermatitis. J Ethnopharmacol. 2015;165:54-60.

27. Park HJ, Choi WS, Lee WY, Choi Y, Park C, Kim JH, Hong KH, Song H. A nove mouse model of atopic dermatitis that is Thelper 2 (Th2)-polarized by an epicutaneous allergen. Environ Toxicol Pharmacol. 2017;58:122-30.

28. Fu D, Shang X, Ni Z, Shi G. Shikonin inhibits inflammation and chondrocyte apoptosis by regulation of the PI3K/Akt signaling pathway in a rat model of osteoarthritis. Exp Ther Med. 2016;12(4):2735-40.

29. Zorman J, Susjan P, Hafner-Bratkovic I. Shikonin Suppresses NLRP3 and AIM2 Inflammasomes by Direct Inhibition of Caspase-1. PLoS One. 2016;11(7): e0159826.

30. Kim JH, Jeong JH, Jeon ST, Kim H, Ock J, Suk K, Kim SI, Song KS, Lee WH. Decursin inhibits induction of inflammatory mediators by blocking nuclear factor-kappaB activation in macrophages. Mol Pharmacol. 2006; 69(6):1783-90

31. Park SJ, Cha HS, Lee YH, Kim WJ, Kim DH, Kim EC, Lee KH, Kim TJ. Effect of nodakenin on atopic dermatitis-like skin lesions. Biosci Biotechnol Biochem. 2014;78(9):1568-71.

32. Choi HS, Cho SG, Kim MK, Kim MS, Moon SH, Kim IH, Ko SG. Decursin in Angelica gigas Nakai (AGN) enhances doxorubicin Chemosensitivity in $\mathrm{NCl}$ / ADR-RES ovarian Cancer cells via inhibition of P-glycoprotein expression. Phytother Res. 2016;30(12):2020-6.

33. Matsui K, Tamai S, Ikeda R. Betamethasone, but not tacrolimus, suppresses the development of Th2 cells mediated by Langerhans cell-like dendritic cells. Biol Pharm Bull. 2016;39(7):1220-3.

34. Kim HO, Yang YS, Ko HC, Kim GM, Cho SH, Seo YJ, Son SW, Lee JR, Lee JS, Chang SE, et al. Maintenance therapy of facial seborrheic dermatitis with 0 . 1\% tacrolimus ointment. Ann Dermatol. 2015;27(5):523-30.

35. Weiss J, Zimmermann F. Tribromoethanol (Avertin) as an anaesthetic in mice. Lab Anim. 1999:33(2):192-3.

36. Woo SM, Choi YK, Kim AJ, Yun YJ, Shin YC, Cho SG, Ko SG. Sip-jeon-dea-Botang, a traditional herbal medicine, ameliorates cisplatin-induced anorexia via the activation of JAK1/STAT3-mediated leptin and IL-6 production in the fat tissue of mice. Mol Med Rep. 2016;13(4):2967-72.

37. Ku JM, Hong SH, Kim HI, Seo HS, Shin YC, Ko SG. Effects of Angelicae dahuricae Radix on 2, 4-dinitrochlorobenzene-induced atopic dermatitis-like skin lesions in mice model. BMC Complement Altern Med. 2017;17(1):98

38. d'Ettorre G, Baroncelli S, Micci L, Ceccarelli G, Andreotti M, Sharma P, Fanello G, Fiocca F, Cavallari EN, Giustini N, et al. Reconstitution of intestinal CD4 and Th17 T cells in antiretroviral therapy suppressed HIV-infected subjects: implication for residual immune activation from the results of a clinical trial. PLoS One. 2014;9(10):e109791.

39. Moossavi S, Bishehsari F. Inflammation in sporadic colorectal cancer. Arch Iran Med. 2012;15(3):166-70.

40. Rennert PD, Ichimura T, Sizing ID, Bailly V, Li Z, Rennard R, McCoon P, Pablo $L$, Miklasz S, Tarilonte $L$, et al. T cell, Ig domain, mucin domain-2 genedeficient mice reveal a novel mechanism for the regulation of Th2 immune responses and airway inflammation. J Immunol. 2006;177(7):4311-21.

41. Hamed EA, Zakhary MM, Maximous DW. Apoptosis, angiogenesis, inflammation, and oxidative stress: basic interactions in patients with early and metastatic breast cancer. J Cancer Res Clin Oncol. 2012;138(6): 999-1009.

42. Kryvenko ON, Jankowski M, Chitale DA, Tang D, Rundle A, Trudeau S, Rybicki BA. Inflammation and preneoplastic lesions in benign prostate as risk factors for prostate cancer. Mod Pathol. 2012;25(7):1023-32.

43. Alfano CM, Imayama I, Neuhouser ML, Kiecolt-Glaser JK, Smith AW, Meeske K, McTiernan A, Bernstein L, Baumgartner KB, Ulrich CM, et al. Fatigue, inflammation, and omega-3 and omega- 6 fatty acid intake among breast cancer survivors. J Clin Oncol. 2012;30(12):1280-7.

44. Brandt EB, Sivaprasad U. Th2 cytokines and atopic dermatitis. J Clin Cell Immunol. 2011;2(3):1-25.

45. Oflazoglu E, Simpson EL, Takiguchi R, Grewal IS, Hanifin JM, Gerber HP. CD30 expression on CD1a+ and CD8+ cells in atopic dermatitis and correlation with disease severity. Eur J Dermatol. 2008;18(1):41-9.

46. Kim H, Kim JR, Kang H, Choi J, Yang H, Lee P, Kim J, Lee KW. 7,8,4'Trihydroxyisoflavone attenuates DNCB-induced atopic dermatitis-like symptoms in NC/Nga mice. PLoS One. 2014;9(8):e104938.

47. Choi WJ, Konkit M, Kim Y, Kim MK, Kim W. Oral administration of Lactococcus chungangensis inhibits 2,4-dinitrochlorobenzene-induced atopic-like dermatitis in NC/Nga mice. J Dairy Sci. 2016;99(9):6889-901.

48. Chae HS, Kang OH, Lee YS, Choi JG, Oh YC, Jang HJ, Kim MS, Kim JH, Jeong $\mathrm{SI}$, Kwon DY. Inhibition of LPS-induced iNOS, COX-2 and inflammatory mediator expression by paeonol through the MAPKs inactivation in RAW 264.7 cells. Am J Chin Med. 2009;37(1):181-94.

49. Huang GJ, Bhaskar Reddy MV, Kuo PC, Huang CH, Shih HC, Lee EJ, Yang ML, Leu YL, Wu TS. A concise synthesis of viscolin, and its anti-inflammatory effects through the suppression of iNOS, COX-2, ERK phosphorylation and proinflammatory cytokines expressions. Eur J Med Chem. 2012;48:371-8.

50. Orita K, Hiramoto K, Kobayashi H, Ishii M, Sekiyama A, Inoue M. Inducible nitric oxide synthase (iNOS) and alpha-melanocyte-stimulating hormones of iNOS origin play important roles in the allergic reactions of atopic dermatitis in mice. Exp Dermatol. 2011;20(11):911-4.

51. Liew FY, Li Y, Severn A, Millott S, Schmidt J, Salter M, Moncada S. A possible novel pathway of regulation by murine T helper type-2 (Th2) cells of a Th1 cell activity via the modulation of the induction of nitric oxide synthase on macrophages. Eur J Immunol. 1991;21(10):2489-94.

52. Triggiani M, Petraroli A, Loffredo S, Frattini A, Granata F, Morabito P, Staiano Rl, Secondo A, Annunziato L, Marone G. Differentiation of monocytes into macrophages induces the upregulation of histamine $\mathrm{H} 1$ receptor. J Allergy Clin Immunol. 2007;119(2):472-81.

53. Homey B, Meller S, Savinko T, Alenius H, Lauerma A. Modulation of chemokines by staphylococcal superantigen in atopic dermatitis. Chem Immunol Allergy. 2007;93:181-94.

54. Holden CA, Chan SC, Hanifin JM. Monocyte localization of elevated CAMP phosphodiesterase activity in atopic dermatitis. J Invest Dermatol. 1986; 87(3):372-6.

55. Kundu JK, Surh YJ. Emerging avenues linking inflammation and cancer. Free Radic Biol Med. 2012;52(9):2013-37.

\section{Ready to submit your research? Choose BMC and benefit from:}

- fast, convenient online submission

- thorough peer review by experienced researchers in your field

- rapid publication on acceptance

- support for research data, including large and complex data types

- gold Open Access which fosters wider collaboration and increased citations

- maximum visibility for your research: over $100 \mathrm{M}$ website views per year

At BMC, research is always in progress.

Learn more biomedcentral.com/submissions 